\title{
Ovarian Steroid Cell Tumor with Biallelic Adenomatous Polyposis Coli Inactivation in a Patient with Familial Adenomatous Polyposis
}

\author{
Patrick J. Hu, ${ }^{1,2,3,4 * \dagger}$ Stewart M. Knoepp, ${ }^{2,5 \dagger}$ Rong Wu, ${ }^{5}$ and Kathleen R. Cho ${ }^{1,2,5}$ \\ 'Department of Internal Medicine, University of Michigan Medical School, Ann Arbor, MI \\ ${ }^{2}$ University of Michigan Comprehensive Cancer Center, Ann Arbor, MI \\ ${ }^{3}$ Life Sciences Institute, University of Michigan, Ann Arbor, MI \\ ${ }^{4}$ Department of Cell and Developmental Biology, University of Michigan Medical School, Ann Arbor, Ml \\ ${ }^{5}$ Department of Pathology, University of Michigan Medical School, Ann Arbor, MI
}

\begin{abstract}
Familial adenomatous polyposis (FAP) is an autosomal dominant cancer predisposition syndrome that accounts for approximately $0.5-1 \%$ of all colorectal cancer cases. It is caused by germline mutations in the gene encoding the adenomatous polyposis coli (APC) tumor suppressor. Somatic APC inactivation due to mutation or loss of heterozygosity (LOH) promotes the development of adenomatous polyps by stabilizing the transcriptional coactivator $\beta$-catenin. Although colorectal cancer is by far the most common malignancy seen in FAP patients, the widespread use of prophylactic colectomy in these patients has increased the clinical importance of extracolonic tumors that are part of the neoplastic spectrum in FAP. Many of these tumors exhibit LOH or somatic APC mutation, strongly supporting a causative role of APC inactivation in their pathogenesis. Here we describe a 47-year-old female FAP patient with clinical manifestations of virilization who was found to have an ovarian steroid cell tumor, a rare neoplasm not known to be associated with FAP. Immunohistochemical analysis of the ovarian tumor demonstrated strong nuclear $\beta$-catenin staining consistent with somatic APC inactivation, and molecular analysis confirmed biallelic APC inactivation in the tumor. Our findings provide the first evidence that ovarian steroid cell tumors may be an extracolonic manifestation of FAP and implicate $\beta$-catenin activation as an oncogenic mechanism in ovarian steroid cell tumorigenesis. (c) 20II Wiley Periodicals, Inc.
\end{abstract}

\section{INTRODUCTION}

Familial adenomatous polyposis (FAP) is an autosomal dominant cancer predisposition syndrome characterized by extensive colorectal polyposis and early-onset colorectal cancer. FAP is caused by germline mutations that result in truncation of the adenomatous polyposis coli $(A P C)$ tumor suppressor protein (Groden et al., 1991; Nishisho et al., 1991). Wild-type $A P C$ acts in the Wnt signaling pathway to regulate cell proliferation and differentiation, primarily by binding to and promoting the degradation of the transcriptional coactivator $\beta$-catenin (Aoki and Taketo, 2007). Somatic inactivation of the wild-type $A P C$ allele is thought to promote colorectal polyposis in FAP patients by stabilizing $\beta$-catenin and constitutively activating $\beta$-catenin/TCF4 transcriptional complexes (Korinek et al., 1997; Morin et al., 1997). Mutation of the wild-type $A P C$ allele in the majority of colorectal adenomas in FAP patients indicates that $A P C$ inactivation is a critical early event in the pathogenesis of colorectal cancer in FAP patients (Miyoshi et al., 1992; Miyaki et al., 1994). Although FAP only accounts for $\sim 0.5-1 \%$ of all colorectal cancer cases (Half et al., 2009; Fearon, 2011), the pathophysiologic underpinnings of FAP have proven to be highly relevant to sporadic colorectal cancers, the majority of which harbor mutations that activate Wnt signaling (Segditsas and Tomlinson, 2006).

FAP is associated with a variety of extracolonic tumors. Compared with the general population, FAP patients are at increased risk of developing desmoid tumors, hepatoblastoma, and tumors of the upper gastrointestinal tract, thyroid gland, brain, pancreas, and adrenal glands (Marchesa et al., 1997; Smith et al., 2000; Shah and Lindor, 2010). The demonstration that both $A P C$ alleles are frequently mutated in these extracolonic

\footnotetext{
${ }^{\dagger}$ Patrick J. Hu and Stewart M. Knoepp contributed equally to this work.

Supported by: American Cancer Society Research Scholar Grant number: RSG-10-132-01-DDC.

*Correspondence to: Patrick J. Hu, 6403 LSI, 210 Washtenaw Avenue, Ann Arbor, MI 48109-2216. E-mail: pathu@umich.edu

Received 11 August 2011; Accepted 18 October 2011

DOI 10.1002/gcc.20953

Published online 15 November 2011 in

Wiley Online Library (wileyonlinelibrary.com).
} 
tumors (Miyaki et al., 1993, 2000; Hamilton et al., 1995; Kurahashi et al., 1995; Wakatsuki et al., 1998; Abraham et al., 2000, 2001; Groves et al., 2002; Blaker et al., 2004; Hosogi et al., 2009; Gaujoux et al., 2010) suggests that $A P C$ inactivation is critical to the pathogenesis of most if not all tumors to which FAP patients are predisposed.

Although colorectal cancer has historically been the major cause of death in FAP patients, the routine incorporation of prophylactic colectomy into the clinical management of FAP patients has drastically reduced colorectal cancer-related mortality in this population. This has resulted in a concomitant increase in the morbidity and mortality associated with extracolonic neoplasms known to be associated with FAP (Bertario et al., 1994; Belchetz et al., 1996; Galle et al., 1999). Therefore, characterizing the full spectrum of FAP-associated neoplasms and understanding their pathogenesis has become increasingly important to the clinical management of FAP patients.

Here we describe an FAP patient with an ovarian steroid cell tumor exhibiting nuclear $\beta$-catenin localization and biallelic inactivation of $A P C$. This report provides the first evidence that ovarian steroid cell tumors are part of the FAP neoplastic spectrum and implicates dysregulation of Wnt signaling in the pathogenesis of ovarian steroid cell tumors.

\section{MATERIALS AND METHODS}

This study was reviewed by the Institutional Review Board at the University of Michigan Medical School and designated as exempt. Tissue samples were prepared utilizing standard formalin fixation followed by automated dehydration and paraffin-embedding, resulting in formalin-fixed paraffin-embedded (FFPE) tissue. Sections for light microscopy were stained with hematoxylin and eosin (H\&E). Immunohistochemistry (IHC) was performed on unstained FFPE tissue using a Ventana Autostainer (Ventana Medical Systems, Tucson, AZ). Incubation with a mouse monoclonal antibody directed against $\beta$-catenin ( $1 / 50$ dilution; BD Biosciences, San Jose, CA) was performed for $32 \mathrm{~min}$ after antigen retrieval with $\mathrm{CC} 2$ buffer ( $\mathrm{pH}$ 6.0) at $91^{\circ} \mathrm{C}$ for $24 \mathrm{~min}$. Incubation with a mouse monoclonal antibody directed against inhibin (prediluted; Ventana Medical Systems) was performed for $28 \mathrm{~min}$ after antigen retrieval for 24 min with CC1M buffer ( $\mathrm{pH} 8.5$ ) at $95^{\circ} \mathrm{C}$ for $24 \mathrm{~min}$. Positive and negative controls were performed in parallel. Slides were reviewed and diagnosed by consensus of two pathologists (SK and KC) in conjunction with a pathology multidisciplinary consensus conference.

\section{APC and CTNNBI Sequence Analysis}

Genomic DNA was extracted from FFPE tissue sections using standard techniques. Briefly, sections were deparaffinized in xylene, then rehydrated through graded ethanols and water. Undesired areas of tissue were manually microdissected off the sections using H\&Estained sections as dissection guides. Remaining tissues were scraped into $1.5 \mathrm{ml}$ tubes and incubated with Gentra Puregene cell lysis solution (Qiagen, Valencia, CA) and DNA extraction was carried out according to the manufacturer's protocol. The entirety of CTNNB1 exon 3 was amplified using a forward primer in exon 2 (CGTGGACAATGGCTACTCAA) and reverse primer in exon 4 (TGCATACTGTCCATC AATA). The PCR products were sequenced en masse using a primer in exon 3 (GGAGTTGGA CATGGCCATGGAA). A DNA fragment encompassing the subject's known germline $A P C$ deletion (3927-3931del AAAGA) was amplified using forward primer (GATGAAATAGGATGTAATC AGACG) and reverse primer (TCTGCTGGA TTTGGTTCTAGG). The APG PCR products from tumor and non-neoplastic (fallopian tube) tissues were sequenced en masse. In addition, $A P C$ PCR products were gel purified (Geneclean III kit, MP Biomedicals, LLC, OH) and cloned into the Zero blunt TOPO vector (Invitrogen, Carlsbad, CA). Individual clones (11 clones from each tissue sample) were selected and sequenced using SP6 primers. Sanger sequencing was performed by the University of Michigan's DNA Sequencing Core.

\section{Case Report}

A 47-year-old woman with FAP was seen recently for evaluation of an adenocarcinoma at her ileostomy site. She was diagnosed with FAP in 1982, when she was found to have colorectal polyposis and a rectal adenocarcinoma. At that time she underwent complete proctocolectomy with end ileostomy. Last year she noted the development of a friable growth at her ileostomy site. Histopathologic analysis of the excised growth revealed an invasive adenocarcinoma 


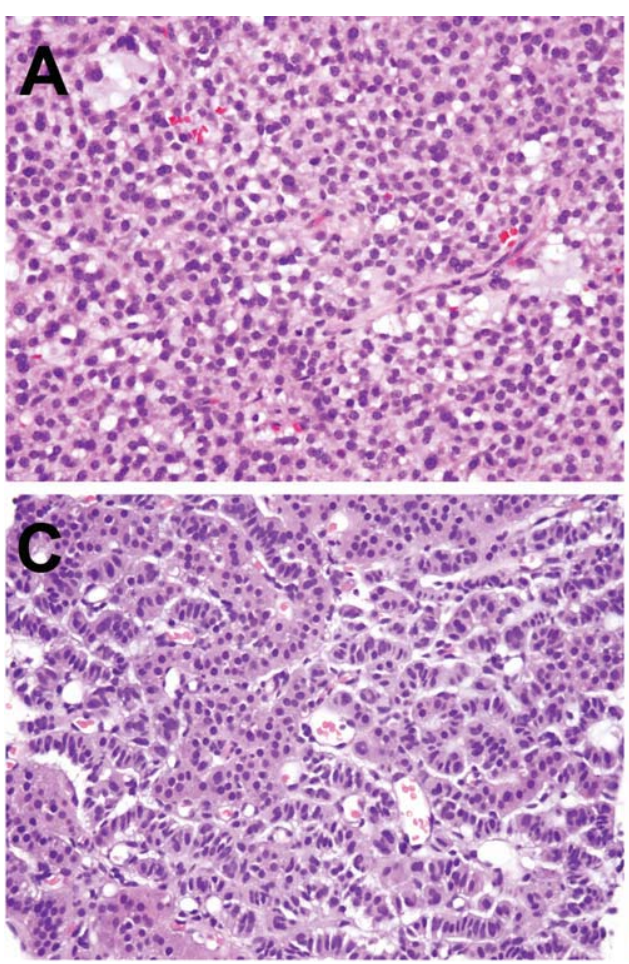

Figure I. $\beta$-catenin immunohistochemistry (IHC). A, B: Ovarian steroid cell tumor showing (A) cells with eosinophilic cytoplasm $(\mathrm{H} \& \mathrm{E}, \times 400)$ and $(\mathrm{B}) \boldsymbol{\beta}$-catenin IHC demonstrating diffuse nuclear and cytoplasmic staining $(\times 400)$. C,D: Adrenocortical adenoma

arising within a tubulovillous adenoma. Postoperatively the growth recurred, and she was seen in clinic for further management recommendations.

Past medical history was remarkable for gastric polyps identified on esophagogastroduodenoscopy 4 years ago. She had a total thyroidectomy in 1994. Family history was remarkable for a 56-year-old maternal half-brother with numerous colonic polyps diagnosed at age 46 and a 55-year-old maternal half-brother with a history of gastric polyps as an infant. Her mother died 3 years ago of complications from lymphoma. Physical exam was remarkable for morbid obesity and hirsutism. Androgen levels were not measured. Molecular analysis of a peripheral blood specimen revealed the presence of a five-nucleotide deletion within the mutation cluster region of exon 15 of the $A P C$ gene (39273931delAAAGA) resulting in a frameshift at amino acid position 1309 and subsequent premature termination codon at amino acid position 1312.

Esophagogastroduodenoscopy revealed no abnormalities. Balloon-assisted lower enteroscopy showed multiple sessile polyps, biopsies of which revealed adenoma. Computed tomography of the chest, abdomen, and pelvis with intravenous and

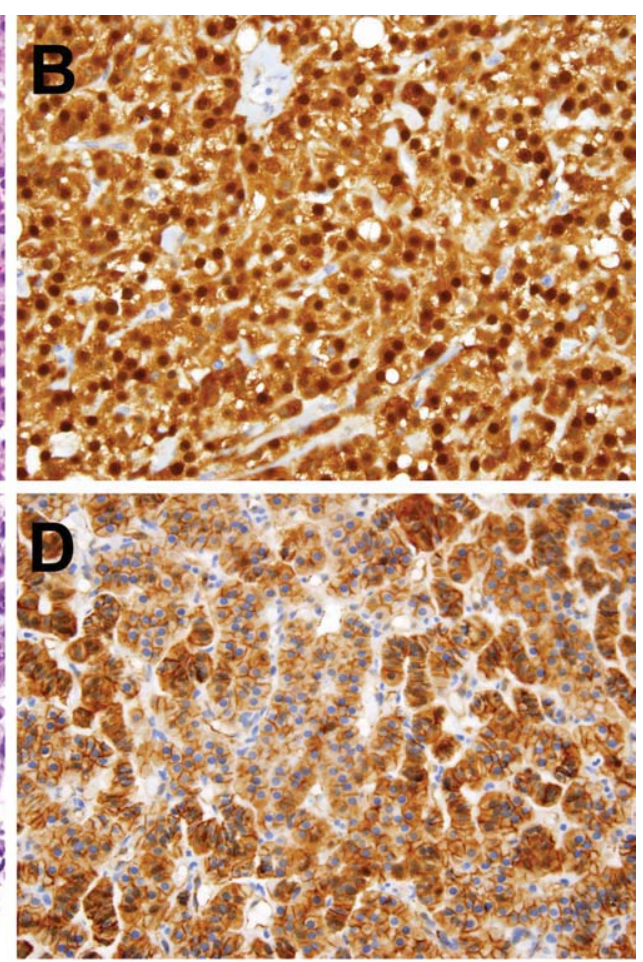

showing (C) cells with eosinophilic cytoplasm arranged in cords and ribbons $(\mathrm{H} \& \mathrm{E}, \times 400)$ and $(\mathrm{D}) \boldsymbol{\beta}$-catenin IHC revealing a membranous staining pattern $(\times 400)$.

oral contrast demonstrated the presence of multiple left adrenal nodules and a $3.5 \times 2.8 \mathrm{~cm}$ right adnexal mass. The largest adrenal nodule and the adnexal mass exhibited increased 2-deoxy-2$\left({ }^{18} \mathrm{~F}\right)$ fluoro-D-glucose (FDG) avidity on positron emission tomography. Core biopsy of the left adrenal mass revealed cortical adenoma (Fig. 1C). The patient subsequently underwent resection of the distal small bowel and the ileostomy as well as right salpingo-oophorectomy.

\section{RESULTS}

Gross examination of the right ovary revealed a symmetrically enlarged $4.3 \mathrm{~cm}$ ovary with a smooth surface. The fallopian tube was unremarkable. Sectioning of the ovary revealed predominant replacement with two wellcircumscribed tan-pink nodules separated by a thin fibrous band. Focal hemorrhage was present in both nodules.

On microscopic examination, the tumor consisted predominantly of a diffuse pattern of rounded cells with distinct borders and moderate to abundant eosinophilic cytoplasm (Figs. 1A and 

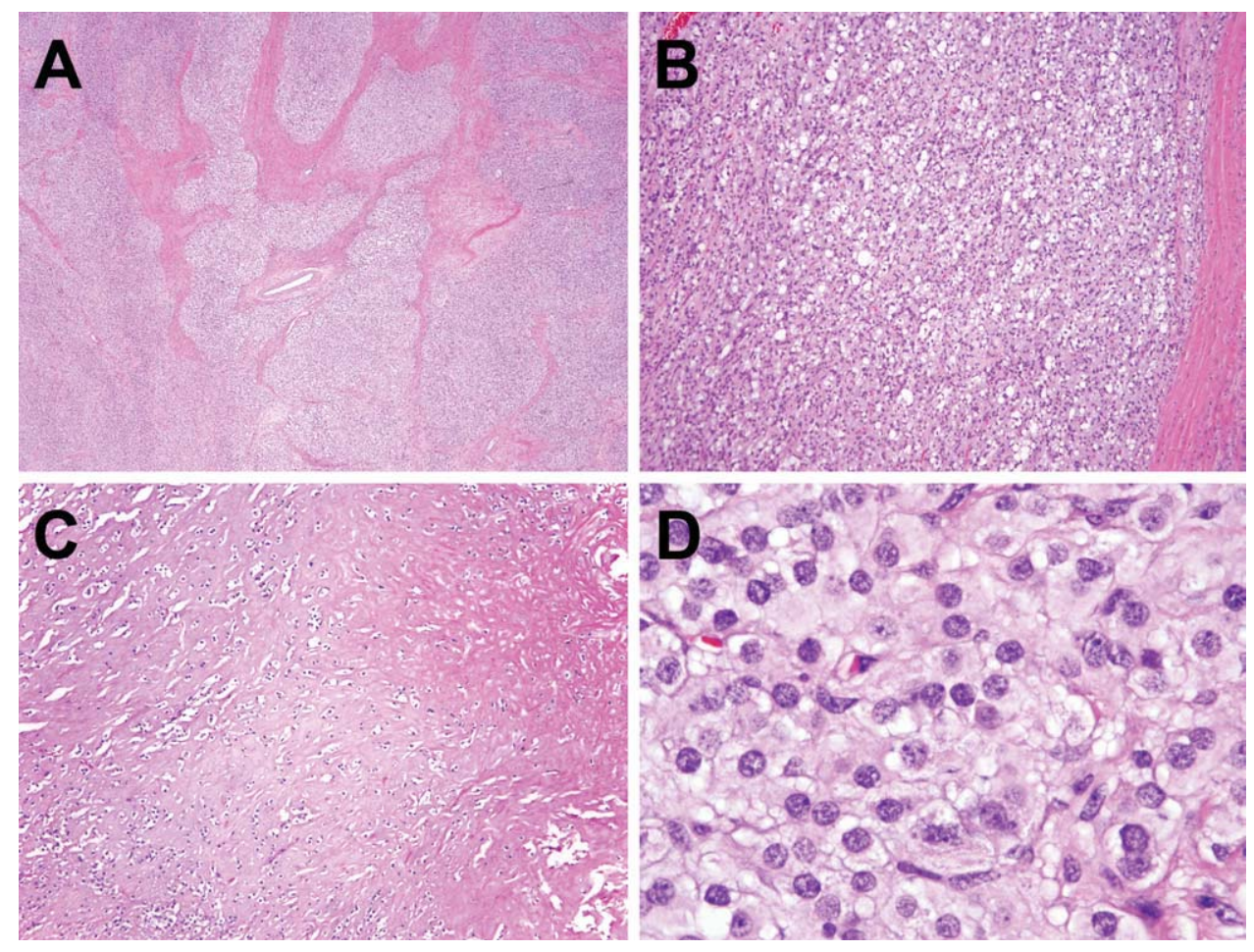

\begin{abstract}
Figure 2. Ovarian steroid cell tumor, not otherwise specified. A: Tumor cells with focal separation by fibrous stroma (H\&E stain, $\times 40)$. B: Diffuse nest of tumor cells with eosinophilic to focally clear cytoplasm (H\&E stain, $\times 200)$. C: Hyalinized area of tumor $(H \& E$ stain, $\times 200)$. D: Characteristic round to polygonal cells with eosinophilic cytoplasm and distinct cell borders (H\&E stain, $\times I, 000)$.
\end{abstract}

2D). Focally the tumor cells were separated by bands of fibrous stroma (Fig. 2A), showed cytoplasmic clearing (Fig. 2B), or showed stromal hyalinization (Fig. 2C). Tumor cell nuclei showed distinct but small nucleoli with granular chromatin (Fig. 2D). Reinke crystals were not present and mitotic activity was negligible. The cytomorphologic features are consistent with a steroid cell tumor, not otherwise specified. The tumor cells lacked any cytomorphologic features suggestive of a granulosa cell tumor (i.e., angulated nuclei, nuclear grooves, mitoses, or high nuclear-to-cytoplasmic ratio). Features suggestive of malignancy (i.e., mitotic activity above 2/high-powered field, necrosis, nuclear atypia, or tumor size greater than $7 \mathrm{~cm}$ (Hayes and Scully, 1987) were not observed. Immunohistochemical staining for $\beta$-catenin showed a strong, diffuse pattern of staining in nuclei and cytoplasm (Fig. 1B). Intervening endothelial cells from vasculature did not show $\beta$-catenin staining (Fig. 1B). An immunostain for inhibin showed focal granular cytoplasmic staining but was negative in most tumor cells (data not shown).

H\&E staining of a core biopsy specimen obtained from the FDG-avid left adrenal nodule showed a characteristic heterogeneity to tumor cell nuclei ranging from uniform cells with eosinophilic cytoplasm arranged in a corded, trabecular pattern with delicate vasculature (Fig. 1C) to more diffuse sheets of cells with pale-staining, lipid-rich cytoplasm (data not shown). Neither nuclear enlargement nor pleomorphism was present. Immunohistochemical staining for $\beta$-catenin showed a diffuse membranous staining pattern without nuclear accumulation (Fig. 1D) distinct from the pattern seen in the ovarian tumor (Fig. $1 \mathrm{~B})$.

The prominent nuclear localization of $\beta$-catenin seen in the ovarian tumor but not in the adrenal tumor (compare Fig. 1B and D) is consistent with the possibility that the wild-type $A P C$ allele was specifically mutated or lost in the ovarian tumor. To test this possibility, the region of the $A P C$ gene flanking the exon 15 germline mutation was PCR-amplified from genomic DNA isolated from both adrenal and ovarian tumors as well as from non-neoplastic tissue from the fallopian tube. Sequencing of PCR products confirmed the presence of both wild-type and mutated $A P C$ alleles in both fallopian tube and 
A

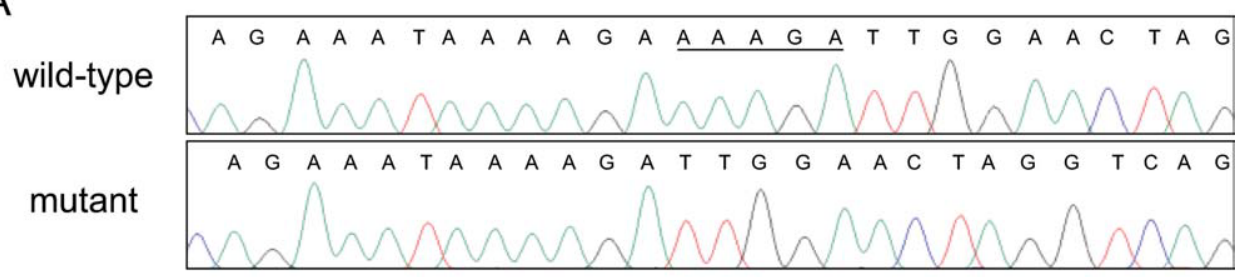

B

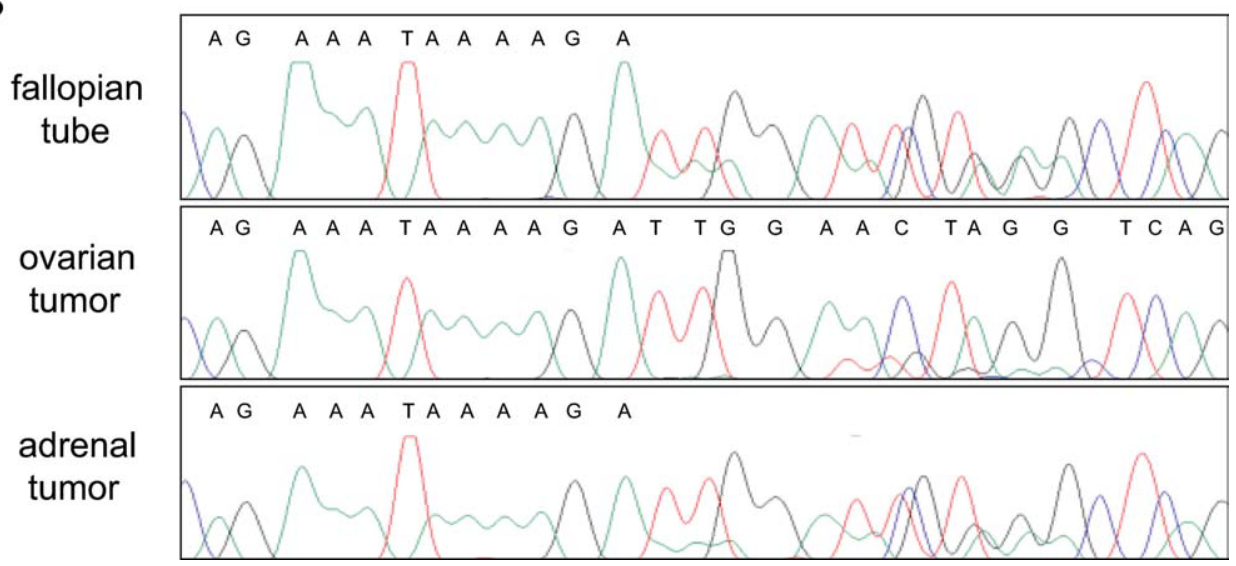

Figure 3. APC sequences amplified from genomic DNA isolated from patient tumor specimens. A: Wild-type and germline mutant APC clones demonstrating the presence of the 3927-393IdelAAAGA mutation. Nucleotides in the wild-type allele that are deleted in the mutant allele are underlined. B: Sequences of APC PCR products amplified from genomic DNA isolated from normal fallopian tube, ovarian steroid cell tumor, and adrenal core biopsy specimens.

adrenal tumor samples (Fig. 3). Notably, $A P C$ sequences from the ovarian tumor sample suggested the presence of reduced amounts of wildtype $A P C$ compared with mutant $A P C$ (Fig. 3B). To confirm this, PCR products from fallopian tube and ovarian tumor samples were cloned, and eleven cloned inserts derived from each template were sequenced. As expected, half of the fallopian tube clones were wild-type (5/11). In contrast, nine of eleven clones from the ovarian tumor contained the germline deletion. This is consistent with somatic loss of the wild-type $A P C$ allele in the ovarian tumor. The small amount of wild-type DNA amplified from this tumor (Fig. $3 \mathrm{~B})$ is likely due to the presence of non-neoplastic cells (e.g., stromal, endothelial and inflammatory) within the tumor (Fig. 2).

In colorectal cancers with wild-type $A P C, \beta$-catenin can be activated by point mutations in exon 3 that alter conserved phosphorylation sites required for its downregulation by glycogen synthase kinase-3 $\beta$ [GSK-3 $\beta$; (Ilyas et al., 1997; Morin et al., 1997)]. To rule out the possibility that the nuclear localization of $\beta$-catenin in the ovarian tumor was a consequence of somatic $\beta$-catenin mutations in exon 3 , exon 3 was
PCR-amplified from genomic DNA isolated from fallopian tube, ovarian tumor, and adrenal tumor samples and sequenced. All three samples revealed wild-type sequence (Fig. 4). Taken together, these data strongly suggest that the nuclear localization of $\beta$-catenin in the ovarian tumor is a consequence of somatic loss of the wild-type $A P C$ allele.

\section{DISCUSSION}

Elucidation of the molecular basis of FAP has led to improvements in the early diagnosis and prevention of colorectal cancer in FAP patients. The resultant increase in their survival will likely lead to the discovery of FAP-associated tumors not previously known to be part of the spectrum of neoplasms seen in FAP. An awareness of this growing spectrum is critical to the optimal clinical management of these patients.

Here we report for the first time an association between ovarian steroid cell tumor and FAP. In spite of the fact that ovarian steroid cell tumors have not previously been reported in FAP patients, our molecular analysis strongly supports the inclusion of ovarian steroid cell tumor as an 


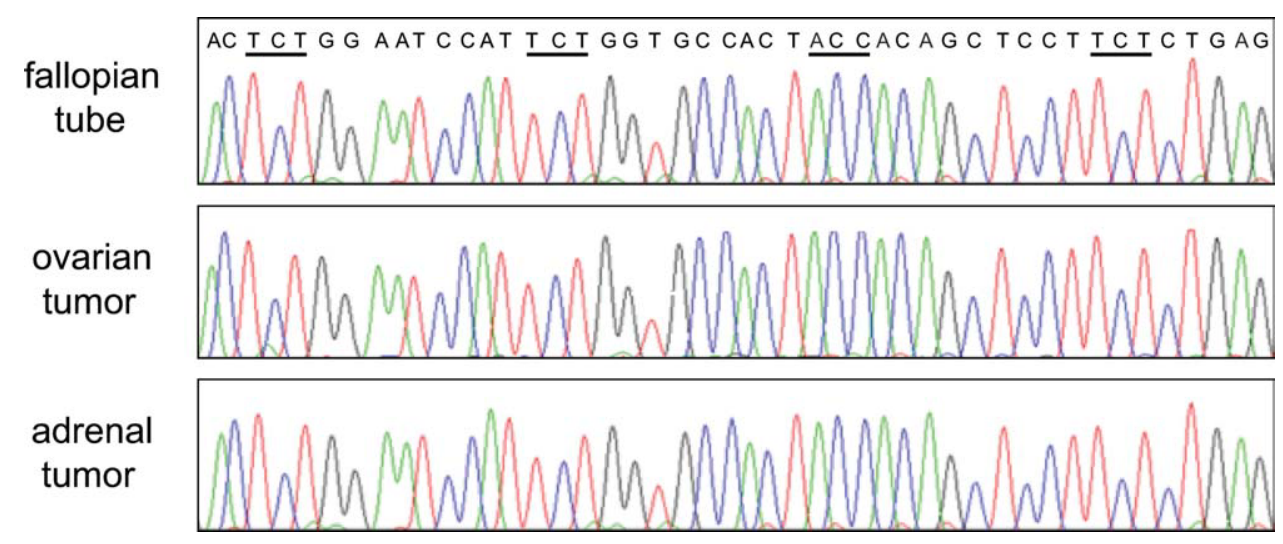

Figure 4. $\beta$-catenin exon 3 sequences of PCR products amplified from genomic DNA. Codons encoding conserved GSK-3 $\beta$ phosphorylation sites that mediate downregulation of $\boldsymbol{\beta}$-catenin are underlined.

extracolonic manifestation of FAP. Immunohistochemical analysis with anti- $\beta$-catenin antibodies clearly demonstrates increased $\beta$-catenin levels and nuclear localization in tumor cells compared with cells outside of the tumor (Fig. 1B). This is consistent with somatic inactivation of $A P C$ in the ovarian tumor and is corroborated by molecular evidence of biallelic $A P C$ inactivation in the ovarian tumor (Fig. 3). Both of these findings are characteristic of tumors that are established extracolonic manifestations of FAP (Miyaki et al., 1993, 2000; Hamilton et al., 1995; Kurahashi et al., 1995; Wakatsuki et al., 1998; Abraham et al., 2000, 2001; Groves et al., 2002; Hosogi et al., 2009; Gaujoux et al., 2010).

The benign nature of the ovarian tumor in this patient is consistent with the association of FAP with benign lesions in several extracolonic tissues (Miyaki et al., 1993; Wakatsuki et al., 1998; Abraham et al., 2000; Blaker et al., 2004; Hosogi et al., 2009; Gaujoux et al., 2010). Notably, conditional expression of a dominant stable $\beta$-catenin mutant in ovarian granulosa cells induces the development of benign vascularized follicular lesions that evolve into granulosa cell tumors. Whereas $\beta$-catenin is expressed in nearly all of the neoplastic cells in these specimens, immunohistochemical analysis revealed that nuclear $\beta$-catenin was generally more prominent in the premalignant lesions than in the granulosa cell tumors (Boerboom et al., 2005). This observation provides additional support for the idea that $A P C$ inactivation and the subsequent stabilization of $\beta$-catenin are early events in carcinogenesis.

Although somatic $A P C$ mutations have been identified in adrenal cortical tumors from FAP patients (Wakatsuki et al., 1998; Hosogi et al., 2009; Gaujoux et al., 2010), the paucity of nuclear $\beta$-catenin staining in this patient's adrenal adenoma (Fig. 1D), coupled with the retention of the wild-type $A P C$ allele (Fig. 3B) and the absence of mutations in exon 3 of $\beta$-catenin in the tumor (Fig. 4), suggest that somatic activation of Wnt signaling is not the basis for its pathogenesis in this case. Somatic mutations in other molecules and pathways that are associated with adrenal tumorigenesis, such as TP53 and insulin-like growth factor 2 signaling (Stratakis, 2003), may have played a role in its development in this patient. Her germline $A P C$ mutation may also have contributed to its pathogenesis, as the incidence of adrenal adenoma in FAP patients is higher than that in the general population (Marchesa et al., 1997; Smith et al., 2000).

Ovarian steroid cell tumors account for less than $0.1 \%$ of all ovarian tumors (Scully, 1979). Virtually nothing is known about their pathogenesis. Our demonstration of nuclear localization of $\beta$-catenin and biallelic $A P C$ inactivation in this tumor (Figs. 1 and 3) suggests that Wnt pathway activation can lead to the development of ovarian steroid cell tumors. The identification of activating $\beta$-catenin mutations in a significant percentage of sporadic tumors that are part of the FAP neoplastic spectrum (Abraham et al., 2001; Garcia-Rostan et al., 2001; Curia et al., 2008; Lazar et al., 2008; Bonnet et al., 2011; Ellison et al., 2011) suggests that Wnt pathway activation may also contribute to tumorigenesis in at least a subset of sporadic ovarian steroid cell tumors. 


\section{REFERENCES}

Abraham SC, Nobukawa B, Giardiello FM, Hamilton SR, Wu TT. 2000. Fundic gland polyps in familial adenomatous polyposis: Neoplasms with frequent somatic adenomatous polyposis coli gene alterations. Am J Pathol 157:747-754.

Abraham SC, Wu TT, Klimstra DS, Finn LS, Lee JH, Yeo CJ, Cameron JL, Hruban RH. 2001. Distinctive molecular genetic alterations in sporadic and familial adenomatous polyposis-associated pancreatoblastomas: Frequent alterations in the $A P C /$ beta-catenin pathway and chromosome 11p. Am J Pathol 159:1619-1627.

Aoki K, Taketo MM. 2007. Adenomatous polyposis coli $(A P C)$ : A multi-functional tumor suppressor gene. J Cell Sci 120:3327-3335.

Belchetz LA, Berk T, Bapat BV, Cohen Z, Gallinger S. 1996. Changing causes of mortality in patients with familial adenomatous polyposis. Dis Colon Rectum 39:384-387.

Bertario L, Presciuttini S, Sala P, Rossetti C, Pietroiusti M. 1994. Causes of death and postsurgical survival in familial adenomatous polyposis: Results from the Italian Registry. Italian Registry of Familial Polyposis Writing Committee. Semin Surg Oncol 10:225-234.

Blaker H, Sutter C, Kadmon M, Otto HF, Von Knebel-Doeberitz M, Gebert J, Helmke BM. 2004. Analysis of somatic APC mutations in rare extracolonic tumors of patients with familial adenomatous polyposis coli. Genes Chromosomes Cancer 41:93-98.

Boerboom D, Paquet M, Hsieh M, Liu J, Jamin SP, Behringer RR, Sirois J, Taketo MM, Richards JS. 2005. Misregulated Wnt/beta-catenin signaling leads to ovarian granulosa cell tumor development. Cancer Res 65:9206-9215.

Bonnet S, Gaujoux S, Launay P, Baudry C, Chokri I, Ragazzon B, Libe R, Rene-Corail F, Audebourg A, Vacher-Lavenu MC, Groussin L, Bertagna X, Dousset B, Bertherat J, Tissier F. 2011. Wnt/beta-catenin pathway activation in adrenocortical adenomas is frequently due to somatic CTNNB1-activating mutations, which are associated with larger and nonsecreting tumors: A study in cortisol-secreting and -nonsecreting tumors. J Clin Endocrinol Metab 96:E419-E426.

Curia MC, Zuckermann M, De Lellis L, Catalano T, Lattanzio R, Aceto G, Veschi S, Cama A, Otte JB, Piantelli M, Mariani-Costantini R, Cetta F, Battista P. 2008. Sporadic childhood hepatoblastomas show activation of beta-catenin, mismatch repair defects and p53 mutations. Mod Pathol 21:7-14.

Ellison DW, Kocak M, Dalton J, Megahed H, Lusher ME, Ryan SL, Zhao W, Nicholson SL, Taylor RE, Bailey S, Clifford SC. 2011. Definition of disease-risk stratification groups in childhood medulloblastoma using combined clinical, pathologic, and molecular variables. J Clin Oncol 29:1400-1407.

Fearon ER. 2011. Molecular genetics of colorectal cancer. Annu Rev Pathol 6:479-507.

Galle TS, Juel K, Bulow S. 1999. Causes of death in familial adenomatous polyposis. Scand J Gastroenterol 34:808-812.

Garcia-Rostan G, Camp RL, Herrero A, Carcangiu ML, Rimm DL, Tallini G. 2001. Beta-catenin dysregulation in thyroid neoplasms: down-regulation, aberrant nuclear expression, and CTNNB1 exon 3 mutations are markers for aggressive tumor phenotypes and poor prognosis. Am J Pathol 158:987-996.

Gaujoux S, Pinson S, Gimenez-Roqueplo AP, Amar L, Ragazzon B, Launay P, Meatchi T, Libe R, Bertagna X, Audebourg A, Zucman-Rossi J, Tissier F, Bertherat J. 2010. Inactivation of the $A P C$ gene is constant in adrenocortical tumors from patients with familial adenomatous polyposis but not frequent in sporadic adrenocortical cancers. Clin Cancer Res 16:5133-5141.

Groden J, Thliveris A, Samowitz W, Carlson M, Gelbert L, Albertsen H, Joslyn G, Stevens J, Spirio L, Robertson M, Sargeant L, Krapcho K, Wolff E, Burt R, Hughes JP, Warrington J, McPherson J, Wasmuth J, Le Paslier D, Abderrahim H, Cohen D, Leppert M, White R. 1991. Identification and characterization of the familial adenomatous polyposis coli gene. Cell 66:589-600.

Groves C, Lamlum H, Crabtree M, Williamson J, Taylor C, Bass S, Cuthbert-Heavens D, Hodgson S, Phillips R, Tomlinson I. 2002. Mutation cluster region, association between germline and somatic mutations and genotype-phenotype correlation in upper gastrointestinal familial adenomatous polyposis. Am J Pathol 160:2055-2061.

Half E, Bercovich D, Rozen P. 2009. Familial adenomatous polyposis. Orphanet J Rare Dis 4:22.
Hamilton SR, Liu B, Parsons RE, Papadopoulos N, Jen J, Powell SM, Krush AJ, Berk T, Cohen Z, Tetu B, Burger PC, Wood PA, Taqi F, Booker SV, Petersen GM, Offerhaus GJA, Tersmette AC, Giardiello FM, Vogelstein B, Kinzler KW. 1995. The molecular basis of Turcot's syndrome. N Engl J Med 332:839_ 847.

Hayes MC, Scully RE. 1987. Ovarian steroid cell tumors (not otherwise specified). A clinicopathological analysis of 63 cases. Am J Surg Pathol 11:835-845.

Hosogi H, Nagayama S, Kanamoto N, Yoshizawa A, Suzuki T, Nakao K, Sakai Y. 2009. Biallelic APC inactivation was responsible for functional adrenocortical adenoma in familial adenomatous polyposis with novel germline mutation of the $A P C$ gene: Report of a case. Jpn J Clin Oncol 39:837-846.

Ilyas M, Tomlinson IP, Rowan A, Pignatelli M, Bodmer WF. 1997. Beta-catenin mutations in cell lines established from human colorectal cancers. Proc Natl Acad Sci USA 94:10330_ 10334.

Korinek V, Barker N, Morin PJ, van Wichen D, de Weger R, Kinzler KW, Vogelstein B, Clevers H. 1997. Constitutive transcriptional activation by a beta-catenin-Tef complex in $A P C-/-$ colon carcinoma. Science 275:1784-1787.

Kurahashi H, Takami K, Oue T, Kusafuka T, Okada A, Tawa A, Okada S, Nishisho I. 1995. Biallelic inactivation of the $A P C$ gene in hepatoblastoma. Cancer Res 55:5007-5011.

Lazar AJ, Tuvin D, Hajibashi S, Habeeb S, Bolshakov S, Mayordomo-Aranda E, Warneke CL, Lopez-Terrada D, Pollock RE, Lev D. 2008. Specific mutations in the beta-catenin gene (CTNNB1) correlate with local recurrence in sporadic desmoid tumors. Am J Pathol 173:1518-1527.

Marchesa P, Fazio VW, Church JM, McGannon E. 1997. Adrenal masses in patients with familial adenomatous polyposis. Dis Colon Rectum 40:1023-1028.

Miyaki M, Iijima T, Ishii R, Hishima T, Mori T, Yoshinaga K, Takami H, Kuroki T, Iwama T. 2000. Molecular evidence for multicentric development of thyroid carcinomas in patients with familial adenomatous polyposis. Am J Pathol 157:18251827

Miyaki M, Konishi M, Kikuchi-Yanoshita R, Enomoto M, Igari T, Tanaka K, Muraoka M, Takahashi H, Amada Y, Fukayama M, Maeda Y, Iwama T, Mishima Y, Mori T, Koike M. 1994. Characteristics of somatic mutation of the adenomatous polyposis coli gene in colorectal tumors. Cancer Res 54:3011-3020.

Miyaki M, Konishi M, Kikuchi-Yanoshita R, Enomoto M, Tanaka K, Takahashi H, Muraoka M, Mori T, Konishi F, Iwama T. 1993. Coexistence of somatic and germ-line mutations of $A P C$ gene in desmoid tumors from patients with familial adenomatous polyposis. Cancer Res 53:5079-5082.

Miyoshi Y, Nagase H, Ando H, Horii A, Ichii S, Nakatsuru S, Aoki T, Miki Y, Mori T, Nakamura Y. 1992. Somatic mutations of the $A P C$ gene in colorectal tumors: mutation cluster region in the $A P C$ gene. Hum Mol Genet 1:229-233.

Morin PJ, Sparks AB, Korinek V, Barker N, Clevers H, Vogelstein B, Kinzler KW. 1997. Activation of beta-catenin-Tef signaling in colon cancer by mutations in beta-catenin or $A P C$. Science 275:1787-1790.

Nishisho I, Nakamura Y, Miyoshi Y, Miki Y, Ando H, Horii A, Koyama K. Utsunomiva J, Baba S, Hedge P. 1991. Mutations of chromosome 5q21 genes in FAP and colorectal cancer patients. Science 253:665-669.

Scully RE. 1979. Tumors of the Ovary and Maldeveloped Gonads Washington, D.C.: Armed Forces Institute of Pathology. p 413.

Segditsas S, Tomlinson I. 2006. Colorectal cancer and genetic alterations in the Wnt pathway. Oncogene 25:7531-7537.

Shah NB, Lindor NM. 2010. Lower gastrointestinal tract cancer predisposition syndromes. Hematol Oncol Clin North Am 24:1229-1252.

Smith TG, Clark SK, Katz DE, Reznek RH, Phillips RK. 2000. Adrenal masses are associated with familial adenomatous polyposis. Dis Colon Rectum 43:1739-1742.

Stratakis CA. 2003. Genetics of adrenocortical tumors: Gatekeepers, landscapers and conductors in symphony. Trends Endocrinol Metab 14:404-410.

Wakatsuki S, Sasano H, Matsui T, Nagashima K, Toyota T, Horii A. 1998. Adrenocortical tumor in a patient with familial adenomatous polyposis: a case associated with a complete inactivating mutation of the $A P C$ gene and unusual histological features. Hum Pathol 29:302-306. 